\title{
Pierre Corneille, Rodogune
}

\section{Cristina Musio}

\section{(2) OpenEdition}

\section{Journals}

\section{Edizione digitale}

URL: http://journals.openedition.org/studifrancesi/34622

DOI: 10.4000/studifrancesi.34622

ISSN: 2421-5856

\section{Editore}

Rosenberg \& Sellier

\section{Edizione cartacea}

Data di pubblicazione: 1 novembre 2005

Paginazione: 410-411

ISSN: 0039-2944

\section{Notizia bibliografica digitale}

Cristina Musio, «Pierre Corneille, Rodogune», Studi Francesi [Online], 146 (XLIX | II) | 2005, online dal 30 novembre 2015, consultato il 19 avril 2021. URL: http://journals.openedition.org/studifrancesi/34622 ; DOI: https://doi.org/10.4000/studifrancesi.34622

\section{Questo documento è stato generato automaticamente il 19 avril 2021.}

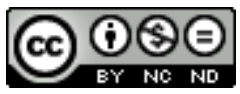

Studi Francesi è distribuita con Licenza Creative Commons Attribuzione - Non commerciale - Non opere derivate 4.0 Internazionale. 


\title{
Pierre Corneille, Rodogune
}

\author{
Cristina Musio
}

\section{NOTIZIA}

PIERRE CORNEILLE, Rodogune, Paris, Gallimard («Collection Folio Théâtre»), 2004.

1 Questa edizione di una delle tragedie meno famose di Corneille è stabilita, presentata e annotata da Jean Serroy, professore all'Università «Stendhal» di Grenoble. Nella prefazione egli rivendica l'alto valore drammaturgico e letterario di Rodogune, pièce rappresentata per la prima volta nella stagione 1644-1645. Si tratta della «plus noire de ses tragédies» (p. 10), nella quale l'elemento pubblico (tragedia dinastica del potere) e quello privato (tragedia familiare dell'amore e dell'odio) sono inscindibili e danno luogo a tensione crescente e complessità d'intreccio. Il ricco «Dossier» conclusivo comprende la cronologia della vita di Corneille, una notizia nella quale Jean Serroy analizza le fonti utilizzate dal drammaturgo e la struttura della pièce («Unités» e «Structures dramatiques»), l'analisi della ricezione e delle messe in scena di Rodogune nei secoli XVIII, XIX e XX, una breve bibliografia, le note al testo e anche un riassunto della tragedia. 